\title{
抗体アフィニティーカラムを用いた 生理活性ペプチドの精製と質量分析計による同定
}

\author{
浮 穴 和 義、筒 井 和 義(広島大・総科・脳科学、 \\ 広島大・統合脳科学プロジェクト研究センター) \\ ukena@hiroshima-u.ac.jp
}

\section{はじめに}

ポストゲノム解析としての新規生理活性物 質の同定と機能解析は、それが生体機能の解 明や創薬のターゲットに直結するために、大 企業のみならず多くのベンチャー企業を巻き 込んだ一大研究開発分野となっている。比較 内分泌分野においても様々な生物のゲノムプ ロジェクトの進行とともに、生理活性物質を コードしている遺伝子の同定が進められてい る。しかしながら、ペプチド性因子の場合、 遺伝子上にコードされている配列から成熟ペ プチドの配列は予想されるものの、実際に生 体内に存在する成熟ペプチドを同定しない限 り内因性物質を同定できたとは言えない。成 熟ペプチドの同定は、その生理機能を正確に 理解するためには極めて重要である。我々は、 最近、鳥類のウズラの脳から生殖腺刺激ホ ルモンの放出を抑制するペプチドを単離・同 定し、生殖腺刺激ホルモン放出抑制ホルモン (Gonadotropin-inhibitory hormone; GnIH) と名付けた ${ }^{1)}$ 。この $\mathrm{GnIH}$ の $末$ 端側の配列 は、LPLRFamideである。この GnIHの 前 駆体遺伝子を同定したところ、C末端側に LPXRFamide (X = L or Q) 構造を持つ $\mathrm{GnIH}$ 遺伝子関連ぺプチドがさらに2つコードさ れていることが明らかとなった2)。さらに、 我々は、脊椎動物における $\mathrm{GnIH}$ 同族ペプチ ドの構造と機能の多様性と統一性を理解する 目的で、哺乳類、鳥類、爬虫類、両生類、魚 類における GnIH 同族ペプチドを同定し、機 能解析を進めている3 12)。この研究過程で、 $\mathrm{GnIH}$ 同族ペプチドの共通配列であるC末端 側の LPXRFamide (X = L or Q) 認識する抗 体を用いた抗体アフィニティー精製と質量分
析計を組み合わせることで、迅速かつ効率よ く成熟ペプチドを同定できることを明らかに してきた $4,6,8,12)$ 。本稿では、それらの方法 を紹介する。抗体を用いたアフィニティー精 製は古くから使われている手法であるし、質 量分析計も近年では比較的身近な分析機器と して使われている。さらに、PCRクローニ ング技術の進展により、以前では特別な技術 が必要であった遺伝子クローニングも、現在 では卒研生が最初に取り掛かる程度の比較的 簡単な実験手法となっている。上述の通り、 ゲノム情報や遺伝子解析で明らかになった生 理活性ペプチドの前駆体タンパク質上に存在 する成熟ペプチドを同定するためには、抗体 アフィニティー精製と質量分析計による同定 は極めて有用な手法である。図 1 に本手法の フローチャートを示す。

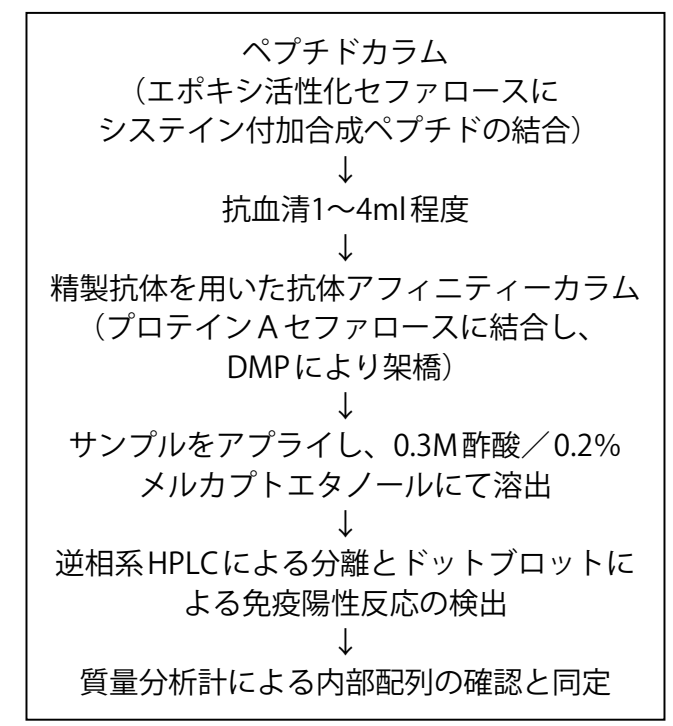

図1 手法のフローチャート 
生理活性ペプチドの共通配列を認識する抗体 を用いた抗体アフィニティーカラムの作製

まず、用いる抗体は、様々な生物種で免 疫組織化学的解析やRIAでの定量などの研 究でも使える共通配列を認識する抗体があれ ばそれが最良である。逆に当然のことである が、ある種の生物特有の配列に対する抗体だ と、別種での解析には全く使えない。我々 が解析を進めている GnIHで言うと、GnIH 同族ペプチドの共通配列であるC末端側の LPXRFamide (X = L or Q) 構造をある程度特 異的に認識する抗体を用いている（特異性は 高すぎず、低すぎず、が重要である)。抗血 清を抗体アフィニティーカラムにする場合、 一旦抗体を血清から精製する必要があるが、 まずエポキシ活性化カラムにシステイン付加 合成ペプチドを結合することによりペプチド カラムを作製し、それに抗血清を通すことで、 特異抗体を精製する。このようにして精製 できた抗体をプロテイン Aセファロースに結 合させて、抗体アフィニティーカラムを作製 する。抗体アフィニティーカラムから目的の リガンドを溶出する際に、プロテインAセフ アロースから抗体が離れてしまわないように、 dimethyl pimelimidate (DMP)などの架橋剤 でプロテイン A と抗体を架橋する。このプロ テイン Aを利用する利点は、免疫グロブリン 分子の Fc 部分に特異的に結合するため、抗 原結合部位への修飾が起こらず、抗体の失活 が最小限に抑えられる点である。実際、我々 は抗体を結合する際に CNBr 活性化担体を用 いた場合、顕著な抗体の失活を経験したこと がある。尚、プロテイン A はヤギ、ニワトリ、 ラットの IgGには結合性を殆ど示さないため、 その際はプロテイン Gを用いる。以下に実 際の手順を記す。

\section{1. ペプチドカラム・抗体精製のために準備 する試薬}

・システイン付加合成ペプチド ( $1 \mathrm{mg}$ 程度)

・エポキシ活性化セファロース6B

(Amersham)

・カップリングバッファー：50mM炭酸ナ
トリウム—重炭酸ナトリウム ( $\mathrm{pH}$ 9.6)

・ブロッキングバッファー：1Mエタノール

アミン、 50 mM Tris-HCl (pH 8.0)

- 0.1M Gly-HCl (pH2.5) : 0.1 M Gly, 0.1 $\mathrm{M} \mathrm{NaCl}$ ( $\mathrm{pH} 2.5)$

- 洗浄 バッファー : $1 \mathrm{M} \mathrm{NaCl}, 1 \%$ Triton $\mathrm{X}-100 、 20$ mM Tris-HCl (pH 7.5)

-TBS : $0.15 \mathrm{M} \mathrm{NaCl} 、 20 \mathrm{mM}$ Tris- $\mathrm{HCl}(\mathrm{pH}$ 7.5)

- $0.15 \mathrm{M} \mathrm{NaCl}$

$\cdot 1 \mathrm{M}$ Tris 溶液 ( $\mathrm{pH}$ 調整不要)

\section{2. ペプチドカラム作製手順}

エポキシ活性化セファロース6B $0.9 \mathrm{~g}$ を蒸 留水約 $200 \mathrm{ml}$ で膨潤させ、BioRadのエコノ パックカラムに充填する (ゲル体積約 $3 \mathrm{ml}$ に なる)。液を涸らした後、システイン付加合 成ペプチド $1 \mathrm{mg}(6 \mathrm{ml}$ カップリングバッファ 一に溶解）を加えて、カラムの両端を閉じ、 室温で一晚振とうする。その後、カップリン

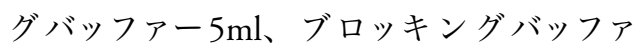
- $20 \mathrm{ml}$ と順次流した後、ブロッキングバッ

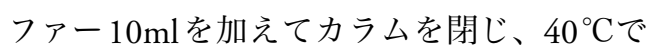
4 時間放置する。その後、蒸留水 $20 \mathrm{ml} 、 0.1$ M Gly-HCl (pH 2.5) 20ml、蒸留水 $20 \mathrm{ml}$ 、洗 浄バッファー $20 \mathrm{ml}$ 、蒸留水 $20 \mathrm{ml} 、 \mathrm{TBS} 20 \mathrm{ml}$ と順次流し、最後に $\mathrm{pH}$ ガ中性であることを $\mathrm{pH}$ 試験紙でチェックしておく。

\section{3. 抗体精製手順}

作製したペプチドカラムへ抗血清 1 ～ $4 \mathrm{ml}$ 加えカラムを閉じ、室温で 1 時間 (または $4^{\circ} \mathrm{C}$ で一晚）振とうする。その後、TBS10ml、洗 浄 バッファー30ml、 TBS30ml、0.15M NaCl $10 \mathrm{ml}$ と順次洗浄した後、0.1M Gly- $\mathrm{HCl}$ (pH2.5) を $1.5 \mathrm{ml}$ (カラム体積の半量) 加え、 $\mathrm{pH}$ 試験 紙でチェックしつつ溶出する。 $\mathrm{pH}$ ガ酸性に変 わったら、0.1 M Gly-HCl (pH 2.5) を4ml更に 加えて、予め 1 M Trisを $200 \mu \mathrm{l}$ (溶出液の1/20量) 入れた容器 (水冷しておく)に回収する。この とき、分光光度計でタンパク質濃度を測定し ておく $(280 \mathrm{~nm} ; 1 \mathrm{mg} / \mathrm{ml}$ のウサギ IgGは約 1.35 である)。約 $1 \mathrm{mg}$ あれば十分である。さらに、 抗体が精製できたことをドットブロット法な 
どで確認しておく。ペプチドカラムは更に、 $0.1 \mathrm{M}$ Gly-HCl (pH2.5) 10mlで洗浄し、蒸 留水で中性になるまで流し、0.02\%アジ化ナ トリウム中で $4^{\circ} \mathrm{C}$ 保存する。数年は保存・再 利用可能である。

\section{4. 抗体アフィニティーカラム作製のために 準備する試薬}

・精製抗体約 $1 \mathrm{mg}$

・抗体結合バッファー: $50 \mathrm{mM}$ ほう酸 $(\mathrm{pH}$ 9.0)

・プロテイン Aセファロース CL-4B

(Amersham)

- 抗体架橋試薬: dimethyl pimelimidate (DMP) $6.6 \mathrm{mg} / \mathrm{ml}[0.2 \mathrm{M}$ トリエタール アミン $(\mathrm{pH} 8.3)$ に溶解 ; 要時調整 $]$

・ブロッキング液 : $0.2 \mathrm{M}$ エタノールアミン (pH 8.0)

- 0.1 M Gly-HCl (pH 2.5): 0.1M Gly, 0.1 M $\mathrm{NaCl}(\mathrm{pH} 2.5)$

- 50 mM Tris- $\mathrm{HCl}(\mathrm{pH} 7.5)$

\section{5. 抗体アフィニティーカラム作製手順}

ペプチドカラムにより精製した抗体約 1 $\mathrm{mg}$ を抗体結合バッファーに対して透析して おく $\left(4^{\circ} \mathrm{C}\right.$ で一晚、途中 3 回程度液交換 $)$ 。プ ロテインAセファロース CL-4B 0.3g を蒸留 水 $60 \mathrm{ml}$ 程度で膨潤させ、BioRadのポリプレ ップカラムに充填する (ゲル体積約 $1 \mathrm{ml}$ にな る)。抗体結合バッファー $10 \mathrm{ml}$ で洗浄した 後、カラムを涸らし、抗体溶液約 $5 \mathrm{ml}$ を加え て室温にて1時間振とうする。溶出し、結合 しなかった素通り画分の吸光度を測定する ことで、確実に抗体がプロテイン Aセファロ ースに結合したことを確認する。抗体結合バ ッファー $5 \mathrm{ml}$ で洗浄し、抗体架橋試薬 $1 \mathrm{ml}$ 加えてカラムを閉じ、室温で1時間振とうす る。ブロッキング液 $5 \mathrm{ml}$ で洗浄後、さらにブ ロッキング液 $5 \mathrm{ml}$ 加えてカラムを閉じ、室 温で2 時間振とうする。その後、0.1 M Gly$\mathrm{HCl}(\mathrm{pH} 2.5)$ 5ml、50mM Tris- $\mathrm{HCl}$ (pH7.5) $20 \mathrm{ml}$ を流し、 $4^{\circ} \mathrm{C}$ 移し、次に述べる手法で 抽出したサンプルと反応させる。

\section{生理活性ペプチドの抽出方法}

組織は液体窒素中でできる限り粉砕し、凍 結した状態で沸騰水の中に投入し、7〜 10分 程度ボイルし、ペプチダーゼを失活させる。 冷却後、終濃度が5\%になるように酢酸を加 え、ポリトロン式のホモゲナイザーでホモゲ ナイズする。15,000xgで20分間遠心し、上 清を回収する。沈殿物は再度 $5 \%$ 酢酸水で抽 出する。組織量が多く不要なタンパク質が多 い場合、終濃度60～75\%アセトンになるよ うにアセトンを加えて冷却し、分子量の大き いタンパク質を沈殿物にして除去する。ただ し、この場合、30残基以上のペプチドにな るとアセトン沈殿により沈殿物となる場合が あるので、注意が必要である。もう1つアセ トン沈殿の際の注意点は、アセトンはポリエ チレンチューブなどを溶かすので、ガラスや テフロンの容器を使わないと質量分析の際に ポリマー状のゴーストピークが出てしまう。 我々の失敗談として、アセトンに溶けてしま う容器を用いたために、質量分析の際にとん でもないことになってしまった経験がある。 アセトン沈殿の場合は、アセトンを蒸発させ る。このようにして抽出した溶液を Sep-Pak (Waters) やBond-Elut(Varian) などの使い捨 ての逆相C18カートリッジカラムにアプライ し、60\%メタノール/0.1\%トリフルオロ酢 酸 (TFA) 溶液にてペプチド性画分を溶出す る。この際、目的のペプチドが疎水性ならば、 まず10\%メタノール / $0.1 \% \mathrm{TFA}$ で洗浄し、 10〜60\%メタノール $/ 0.1 \% \mathrm{TFA}$ 画分を回収 する。回収したサンプルは、凍結乾燥する。 必要な組織量は、対象の材料にもよるが、ウ ズラの視床下部の場合、数百 $\mathrm{mg}$ から $\mathrm{g}$ 程度 あれば十分である。質量分析計での検出では、 実際に解析するサンプルに含まれる組織量は $10 \mathrm{mg}$ 以下で十分に目的のペプチドを検出で きる。

\section{サンプルの抗体アフィニティーカラムへのア プライ・溶出とイムノアッセイ}

上記の凍結乾燥したサンプルは $0.1 \mathrm{M}$ Tris- 
$\mathrm{HCl}(\mathrm{pH}$ 8.4) 2mlで溶かし、抗体アフィニテ イーカラムにアプライし、カラムを閉じた後、 $4{ }^{\circ} \mathrm{C}$ で 1 時間 (または一晚) 振とうする。以下 の作業は $4^{\circ} \mathrm{C}$ の低温室で行う。0.1M Tris- $\mathrm{HCl}$ (pH 8.4) 20mlで洗浄した後、0.3M酢酸 $0.1 \%$ ルカプトエタノールで抗体に結合し た目的の物質を溶出し、1 $\mathrm{ml}$ ずつチューブに 回収していく。通常、最初の $5 \mathrm{ml}$ 程度までに 溶出される。その後、抗体カラムは $0.3 \mathrm{M}$ 酢 酸 $/ 0.1 \%$ メルプトエタノール $30 \mathrm{ml} 、$ 蒸留 水で中性になるまで洗浄し、0.02\%アジ化ナ トリウムを含む $0.1 \mathrm{M}$ Tris- $\mathrm{HCl}(\mathrm{pH} 8.4)$ を加 え $4^{\circ} \mathrm{C}$ 保存する。半年程度なら何度でも再利 用できる。

抗体には非特異的に結合する物質も少な くない。そこで抗体アフィニティーカラムか ら溶出したサンプルを逆相系HPLCにて分 離し、各フラクションをドットブロット法か ELISA法にてイムノアッセイを行い、免疫 反応を確認する。我々は、最も簡単なアッ セイ方法としてニトロセルロースメンブレ ン (ADVANTEC社製ドットブロット用)を 用いたドットブロット法を用いている。こ の場合、目的のペプチドが小さすぎるとメ ンブレンに結合しない場合があり、そのまま の状態では上手く検出できないときがある。 その場合は、0.1\%BSA溶液で溶かしたり、 それを4\%パラホルムアルデヒドや dimethyl suberimidate (DMS) で架橋しキャリアタン パク質と結合したりすることでメンブレンへ の保持を高めるなどの工夫が必要である。ど の手法が良いかは目的の物質によって違うの で、予備実験が必要である。免疫反応が認め られたフラクションを次の質量分析へ進める。

\section{質量分析計を利用した微量分析}

2002年のノーベル化学賞を受賞した田中 耕一博士の話題も相まって、昨今では各大 学の共通施設にも MALDI-TOF-MS や ESITOF-MS の導入が行われているようである。 我々も2000年ごろから、サントリー生物有 機科学研究所の南方宏之博士のご協力を得て、
ESI-Q-TOF-MSを利用してGnIH 同族ペプ チドの同定を行ってきた。また、ここ数年で は学内共通機器分析施設にMALDI-TOF-MS も設置され、分析を行っている。しかしな がら、MALDI-TOF-MSのPSD機能による $\mathrm{MS} / \mathrm{MS}$ 解析力は高くなく、内部配列の確認 には苦しい部分があるが、ESI-Q-TOF-MS を利用した MS/MS 解析はペプチドの同定に 優れている。質量分析法についてのより詳細 な解説は、本テクニカルノートでもサントリ 一生物有機科学研究所の久田美貴博士や安田 明和博士によってなされているので、そちら を参考にしていただきたい（No. 99及び107）。 最近では、組織切片上での生理活性ペプチド の同定も試みられている。質量分析計の利点 は、極めて高感度であることであるために大 量の組織を必要とせず、アミノ酸シークエン サーでの解析が不要な点である。遺伝子配列 が分かっている場合の解析には極めて有用で あり、予め前駆体タンパク質にコードされて いるぺプチド配列の質量值を計算しておき、 それに相当するイオンピークを検出する。尚、 イソロイシンやロイシンのような同一質量值 をもつものの判別は付かないため、質量分析 計のみでのde novoのシークエンスは出来な いが、遺伝子解析から前駆体タンパク質が明 らかな場合は確実な同定が可能である。図2 は、ウシガエルの $\mathrm{GnIH}$ 同族ペプチドである fGRP-RP-2の同定の際の MS/MS スペクトル を示している。2価イオンピーク m/z 1034.14 $[\mathrm{M}+2 \mathrm{H}]^{2+} \mathrm{MS} / \mathrm{MS}$ 解析したもので、内部 配列が確認でき、結果的に fGRP-RP-2であ ることが分かる。尚、質量分析計により、メ チオニンの酸化なども質量值から予想が付く。 グレリンの脂肪酸修飾の同定にも質量分析計 は必須の解析手法である ${ }^{13)}$ 。

\section{最後に}

我々が行ってきた抗体アフィニティー精製 を質量分析計での前処理段階として使う理由 は、組織から単にペプチドを抽出して質量分 析計で検出しょうとした場合、目的の物質の 


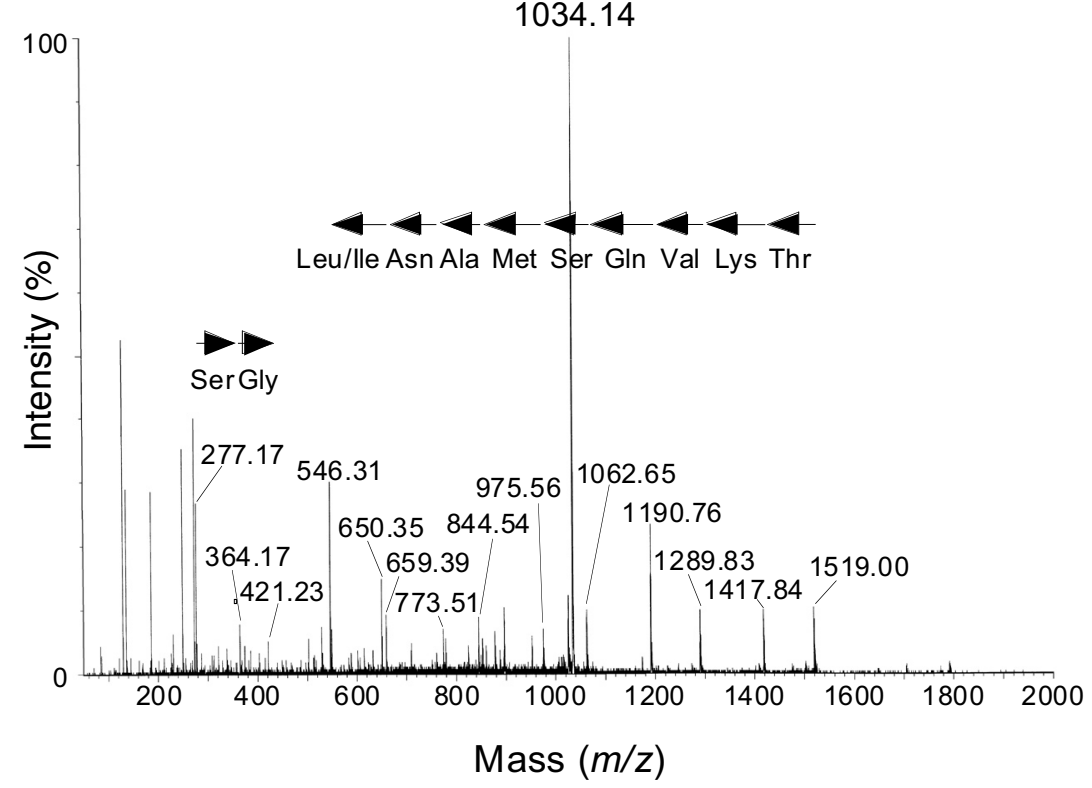

364.17

$277.17 \quad 421.23 \quad 650.35$ H-Tyr-Leu-Ser-Gly-Lys-Thr-Lys-Val-GIn-Ser-Met-Ala-Asn-Leu-Pro-GIn-Arg-Phe-NH $\left.\left.\right|_{y}\right|_{y}$

$\begin{array}{lllll}1519.00 & 1289.83 & 1062.65 \quad 844.54 & 659.39\end{array}$

$\begin{array}{lllll}1417.84 & 1190.76 & 975.56 & 773.51 & 546.31\end{array}$

fGRP-RP-2

図2 fGRP-RP-2のMS/MSスペクトル

イオン化が起こらずに検出できないといつ たことがかなりの頻度で生じるためである。 これは、物質毎のイオン化になりやすさの違 いや、イオン化を邪魔する物質の存在などが 考えられる。同じ組織量でも、抗体アフィニ ティー精製をしたものとしていないものを比 較すると、前者だと容易にイオン化するのに 対し、後者は全くイオン化されずピークが検 出できない場合があることからもこの手法の 優れた点が理解できる。このような手法によ り、我々は表 1 に示したような $\mathrm{GnIH}$ 同族ぺ プチドを同定している。この解析手法や研究 内容は、質量分析計を利用した雑誌の中で最 も権威のある Mass Spectrometry Review誌の 編集長にも注目されたので、GnIHを含めた RFamideペプチドにご興味のある方はそちら
も参考にしていただきたい12)。また、より 少量の組織からの迅速な生理活性ペプチドの 同定手法や定量手法を改良する余地は十分に あるので、今後も検討を重ねていきたい。さ らに、生理活性ペプチドだけでなくタンパク 質でも同様の精製は可能であり、精製後に プロテアーゼ処理することで、ペプチド断片 の質量值を解析し、もとのタンパク質の同定 も簡単に出来ると思われる。ウェスタンブロ ッティングの結果から得られる情報も、質量 分析計による翻訳後修飾を含めた正確なタン パク質の解析を再度行うことで、結果の解釈 が変わってくる可能性も十分にあり得る。

比較内分泌学は、情報伝達物質の構造や機 能の多様性と統一性を理解する学問であるの で、解析の対象となる生物が本来持つ物質を 
表1 同定したGnlH同族ペプチド

\begin{tabular}{|c|c|c|c|}
\hline Sequence & Animal & Name & Reference \\
\hline ANMEAGTMSHFPSLPQRFamide & Rat & RFRP-3 & Ukena et al., 2002 [4] \\
\hline SIKPSAYLPLRFamide & Quail & GnIH & Tsutsui et al., $2000[1]$ \\
\hline SSIQSLLNLPQRFamide & Quail & GnIH-RP-2 & Satake et al., 2001 [2] \\
\hline SLKPAANLPLRFamide & Bullfrog & fGRP & Koda et al., 2002 [7] \\
\hline SIPNLPQRFamide & Bullfrog & fGRP-RP-1 & Ukena et al., 2003 [8] \\
\hline YLSGKTKVQSMANLPQRFamide & Bullfrog & fGRP-RP-2 & Ukena et al., 2003 [8] \\
\hline AQYTNHFVHSLDTLPLRFamide & Bullfrog & fGRP-RP-3 & Ukena et al., 2003 [8] \\
\hline SGTGLSATLPQRFamide & Goldfish & gfLPXRFa-3 & Sawada et al., $2002[6]$ \\
\hline
\end{tabular}

同定し、その機能解析を行うことは重要であ る。特に最近では、各種動物のゲノムプロジ エクトの進展とともに得られる遺伝子情報も 多くなってきた。しかし、冒頭で述べたとお り、内因性の成熟ペプチドは実際に同定しな い限り構造は不明なままである。そのための 方法論として今回紹介した手法が役立てば幸 いである。

\section{謝 辞}

本研究は、サントリー生物有機科学研究所 の南方宏之博士のグループの多大なるご協力 による。また、GnIHの関連研究は、早稲田 大学の菊山榮教授のグループを初め多くの国 内外の研究室との共同研究であり、この場を お借りして感謝申し上げる。また、 GnIH 同 族ペプチドの同定に関する研究は、科学研究 費補助金と材料科学技術振興財団の研究助成 金により行われた。

\section{文 献}

1 ) Tsutsui K, Saigoh E, Ukena K, Teranishi H, Fujisawa Y, Kikuchi M, Ishii S, Sharp PJ. (2000) A novel avian hypothalamic peptide inhibiting gonadotropin release. Biochem. Biophys. Res. Commun. 275: 661-667.

2 ) Satake H, Hisada M, Kawada T, Minakata H, Ukena K, Tsutsui K. (2001) Characterization of a cDNA encoding a novel avian hypothalamic neuropeptide exerting

an inhibitory effect on gonadotropin release. Biochem. J. 354: 379-385.

3 ) Ukena K, Tsutsui K. (2001) Distribution of novel RFamide-related peptidelike immunoreactivity in the mouse central nervous system. Neurosci. Lett. 300: 153-156.

4 ) Ukena K, Iwakoshi E, Minakata H, Tsutsui K. (2002) A novel rat hypothalamic RFamide-related peptide identified by immunoaffinity chromatography and mass spectrometry. FEBS Lett. 512: 255-258.

5 ) Sawada K, Ukena K, Kikuyama S, Tsutsui K. (2002) Identification of a cDNA encoding a novel amphibian growth hormone-releasing peptide and localization of its transcript. J. Endocrinol. 174: 395-402.

6 ) Sawada K, Ukena K, Satake H, Iwakoshi E, Minakata H, Tsutsui K. (2002) Novel fish hypothalamic neuropeptide: Cloning of a cDNA encoding the precursor polypeptide and identification and localization of the mature peptide. Eur. J. Biochem. 269: 6000-6008.

7 ) Koda A, Ukena K, Teranishi H, Ohta S, Yamamoto K, Kikuyama S, Tsutsui K. (2002) A novel amphibian hypothalamic neuropeptide: isolation, localization, and biological activity. Endocrinology 143: 411-419. 
8 ) Ukena K, Koda A, Yamamoto K, Kobayashi T, Iwakoshi-Ukena E, Minakata H, Kikuyama S, Tsutsui K. (2003) Novel neuropeptides related to frog growth hormone-releasing peptide: Isolation, sequence, and functional analysis. Endocrinology 144: 3879-3884.

9 ) Ukena K, Ubuka T, Tsutsui K. (2003) Distribution of a novel avian gonadotropin-inhibitory hormone in the quail brain. Cell Tissue Res. 312: 73-79.

10) Osugi $T$, Ukena $K$, Bentley GE, O'Brien $S$, Moore IT, Wingfield JC, Tsutsui K. (2004) Gonadotropin-inhibitory hormone in Gambel's white-crowned sparrow (Zonotrichia leucophrys gambelli): cDNA identification, transcript localization and functional effects in laboratory and field experiments. J. Endocrinol. 182: 33-42.

11) Ubuka $T$, Bentley GE, Ukena $K$, Wingfield JC, Tsutsui K. (2005) Melatonin induces the expression of gonadotropin-inhibitory hormone in the avian brain. Proc. Natl. Acad. Sci. USA. 102: 3052-3057.

12) Ukena K, Tsutsui K. (2005) A new member of the hypothalamic RFamide peptide family, LPXRFamide peptides: Structure, localization and function (review). Mass Spectrom. Rev. 24: 469-486.

13) Kaiya H, Van Der Geyten S, Kojima M, Hosoda H, Kitajima Y, Matsumoto M, Geelissen S, Darras VM, Kangawa K. (2002) Chicken ghrelin: purification, cDNA cloning, and biological activity. Endocrinology 143: 3454-3463. 